\title{
DAMPAK KEBERADAAN PERGURUAN TINGGI DALAM MENINGKATKAN PELUANG USAHA BAGI MASYARAKAT SEKITAR KAMPUS
}

\author{
Netti Nurlenawati \\ Program Studi Manajemen, Fakultas Bisnis, Universitas Buana Perjuangan Karawang \\ Jl. H.S. Ronggowaluyo Telukjambe Timur Karawang \\ Email: netti.nurlenawati@ubpkarawang.ac.id
}

\begin{abstract}
ABSTRAK
Tujuan penelitian ini adalah untuk menggambarkan persepsi masyarakat terhadap keberadaan Universitas Buana Perjuangan (UBP) Karawang serta menganalisis dampak berdirinya UBP Karawang terhadap peluang-peluang usaha di sekitar kampus.

Penelitian ini merupakan deskriptif kualitatif yang bertujuan untuk menggambarkan fenomena secara kualitatif yang terdapat di lokasi penelitian. Penelitian ini menggunakan studi kasus tunggal (Single Case Study). Penelitian dilaksanakan di lokasi sekitar kampus UBP Karawang (radius 500 m), Desa Puseurjaya dan Sirnabaya dan Sirnabaya Kecamatan Telukjambe Timur Karawang. Dengan penentuan sampel menggunakan Purposive Sampling.. Responden terdiri dari para pedagang di sekitar kampus UBP Karawang, tokoh masyarakat, serta unsur pimpinan UBP Karawang. Sedangkan waktu penelitian mulai bulan Januari sampai dengan Agustus 2017.

Hasil penelitian menunjukkan bahwa keberadaan perguruan tinggi di Puseurjaya dan Sirnabaya memberikan dampak yang positif bagi masyarakat umum yaitu pertama membuka peluang usaha sehingga banyak tenaga kerja yang terserap, baik itu membuka usaha sendiri maupun bekerja pada pengusaha lain. Kedua memunculkan motivasi bagi anak-anak setempat untuk melanjutkan pendidikan pada jenjang tertinggi, sehingga pada akhirnya nanti dapat membangun daerahnya.

Walaupun peluang untuk usaha di sekitar kampus UBP Karawang sangat besar, tetapi belum dimanfaatkan oleh masyarakat setempat. Kendala yang dihadapi oleh masyarakat setempat berupa rendahnya motivasi, kurangnya keberanian menanggung resiko serta kurangnya permodalan sehingga tidak dapat bersaing dengan pengusaha pendatang.

Kata Kunci: dampak, perguruan tinggi, peluang usaha, masyarakat sekitar kampus.
\end{abstract}

\section{ABSTRACT \\ THE IMPACT OF UNIVERSITY EXISTENCE IN IMPROVING BUSINESS OPPORTUNITIES FOR LOCAL COMMUNITIES}

The objective of this research is to describe the perception of communities towards the existence of Universitas Buana Perjuangan (UBP) Karawang and to 
analyze the impact of UBP Karawang's establishment in improving business opportunities around the campus.

This is a descriptive-qualitative research aimed to describe the phenomenon that exists in the research location qualitatively. The research uses a single case study. The research was done around the location of UBP campus (radius of $500 \mathrm{~m}$ ), Puseurjaya village and Sirnabaya sub-district East Telukjambe Karawang using pusposive sampling. The respondents consisted of merchants around the campus, public figures, and high officials of UBP Karawang. The research was done from January to August 2017.

The result of the research suggested that the existence of a university in Puseurjaya and Sirnabaya gives a positive impact for the general communities. Firstly, giving business opportunities such that a lot of manpower are needed, either to open one's own business of work for another entrepreneur. Secondly, giving the local children motivation to continue to higher education so that they can develop their region in the future.

Although the business opportunities around UBP Karawang campus is very big, they still cannot be utilized fully by the local community. The problem faced by the local community consisting of low motivation, lacking courage to take risk, and lacking fund so that they cannot compete with the entrepreneurs that come from outside of the region.

Keywords: impact, university, business opportunity, communities around university

\section{PENDAHULUAN}

Melihat perkembangan bisnis saat ini, bisnis dijadikan sebagai sumber utama mata pencaharian masyarakat. Penyebabnya adalah kebutuhan hidup yang semakin besar dan menuntut untuk kehidupan yang lebih baik. Hal tersebut yang menjadikan alasan masyarakat untuk mengikuti atau menciptakan bisnis sendiri. Pelaku bisnis atau usaha di sini bukan hanya yang bergerak di bidang penghasil produk saja namun penyedia jasa pun kian bermunculan. Salah satu yang mempengaruhi keberlangsungan usaha adalah lingkungan sosial (lokasi).

Lingkungan sosial merupakan aspek dari interaksi manusia melalui kelompok, apakah itu dekat ataupun jauh, yang dapat berpengaruh pada kelangsungan dan pertumbuhan perusahaan (Ancok, 2009). Interaksi sosial tidak akan terjadi bila tidak memenuhi dua syarat, yaitu: adanya kontak sosial (social contact) dan adanya komunikasi (communication). Menurut para ahli sosial, bentuk-bentuk interaksi sosial dapat berupa kerjasama (cooperation), persaingan (competition), akomodasi (accomodation), dan dapat juga berbentuk pertentangan (conflict). Terdapat empat 
cara untuk menyikapi dampak perubahan lingkungan sosial terhadap aktivitas bisnis. Pertama, bahwa perubahan lingkungan sosial secara alamiah menimbulkan peluang maupun ancaman terhadap aktivitas bisnis. Kedua, perubahan lingkungan sosial digunakan oleh organisasi sebagai faktor penentu untuk membuat keputusan berinvestasi. Ketiga, perubahan lingkungan sosial mempengaruhi keputusan organisasi untuk menjalankan bisnis di lokasi tertentu. Dan yang terakhir adalah, perubahan yang ada menuntut organisasi untuk menerapkan cara berpikir baru dalam menjalankan bisnis. (Ancok, 2009).

Terdapat interaksi antara dunia usaha dan lingkungan sosial. Kelompokkelompok dan gaya hidup yang berkembang dalam masyarakat ini, sangat menentukan keberlangsungan bisnis, sebagai suatu proses yang tidak pernah lepas dari lingkungannya. Sebaliknya, dunia usahapun memiliki dampak dan pengaruh balik terhadap lingkungan sosial. Dampak dari dunia usaha banyak mempengaruhi kehidupan masyarakat secara umum baik langsung maupun tidak langsung.

Desa Puseurjaya dan Desa Sirnabaya merupakan dua desa di Kecamatan Telukjambe Timur yang letaknya berdampingan. Lokasi desa ini sangat strategis mengingat perkembangan industri serta kota Karawang ke arah Selatan dan kedua desa ini menjadi desa yang sangat pesat perkembangannya dalam lima tahun terakhir. Jarak desa ini sangat dekat dengan gerbang tol Karawang Barat yaitu sekitar 5 km, demikian juga dengan kawasan industri KIIC (Karawang International Industry City). Industri akan menyebabkan migrasinya penduduk dari luar ke daerah Karawang. Meningkatnya jumlah penduduk tersebut bukan faktor tunggal tetapi merupakan faktor majemuk yang akan memberikan suatu multiplier effect. Dengan masuknya penduduk baru dari luar daerah maka tidak dapat dipungkiri lagi akan terjadi perubahan pada daerah setempat. Baik sosial, ekonomi dan budaya masyarakat setempat.

Di dua desa ini juga terdapat dua Perguruan Tinggi yaitu Universitas Singaperbangsa Karawang (Unsika) yang sudah berstatus perguruan tinggi negeri (PTN) dan Universitas Buana Perjuangan, perguruan tinggi swasta (PTS) yang baru berdiri pada tahun 2014. Keberadaan dua perguruan tinggi tersebut mengakibatkan 
jumlah penduduk di desa tersebut semakin meningkat. Hal ini menyebabkan bertambah banyaknya rumah yang dibangun termasuk rumah yang menjadi tempat kos mahasiswa, berdampak juga pada semakin banyaknya warung makan, usaha jasa cucian, photo copy, mini market dan jenis usaha lainnya. Hal ini akan menyebabkan perubahan sosial ekonomi pada masyarakat setempat.

Terdapat perbedaan pengambilan keputusan antara karyawan pabrik dan mahasiswa dalam menentukan tempat tinggal. Karyawan pabrik memilih tempat tinggal yang murah, walaupun agak jauh dari tempat kerja tidak masalah asalkan terjangkau oleh bus jemputan. Berbeda dengan mahasiswa yang cenderung ingin kos di rumah yang dekat dengan kampus mengingat apabila tempat kos-nya jauh dari kampus maka akan ada biaya transportasi yang harus dikeluarkan, kemungkinan terlambat datang ke kampus akan lebih besar. Semakin dekat tempat tinggal mahasiswa ke kampus semakin banyak kegiatan yang dapat diikuti, selain itu di dekat kampus biasanya banyak warung makan yang harganya sesuai dengan kemampuan mahasiswa.

Dari uraian di atas menunjukkan bahwa disadari ataupun tidak oleh para pebisnis bahwa peluang usaha semakin meningkat dengan adanya perguruan tinggi. Namun demikian tidak semuanya usaha tersebut dimiliki oleh penduduk sekitar kampus, banyak juga pemilik usaha tersebut dari luar kota Karawang, padahal tadinya lahan yang digunakan sebagai tempat berdirinya gedung perguruan tinggi tersebut adalah milik penduduk setempat.

Terdapat perubahan pandangan masyarakat antara dulu dan sekarang terhadap perguruan tinggi. Apabila dulu perguruan tinggi dianggap sebagai menara gading yang tidak tersentuh oleh masyarakat umum, sekarang penilaian tersebut telah berubah. Perguruan tinggi yang baik justru dinilai dari seberapa besar kontribusinya terhadap masyarakat umum.

Dari tiga dharma yang dilaksanakan oleh perguruan tinggi yaitu pendidikan dan pengajaran, penelitian, dan pengabdian kepada masyarakat, dharma ketigalah yang langsung dirasakan oleh masyarakat umum. Dari dharma yang ketiga ini biasanya suatu perguruan tinggi berkesempatan untuk memiliki desa binaan. Suatu 
desa binaan tidak harus jauh dari perguruan tinggi tersebut, apabila lokasi sekitar masih memerlukan pembinaan bahkan harus diprioritaskan.

Berdasarkan hal itu berkaitan dengan pengabdian kepada masyarakat maka perlu adanya penelitian tentang dampak keberadaan perguruan tinggi terhadap peluang usaha bagi masyarakat sekitar kampus. Adapun tujuan penelitian ini adalah untuk menggambarkan persepsi masyarakat terhadap keberadaan UBP Karawang, menganalisis dampak berdirinya UBP Karawang terhadap peluang-peluang usaha di sekitar kampus, serta mendapatkan informasi tentang harapan para pemilik usaha dan masyarakat sekitar kampus terhadap keberadaan UBP Karawang.

\section{METODE PENELITIAN}

Penelitian ini merupakan deskriptif kualitatif yang bertujuan untuk menggambarkan fenomena secara kualitatif yang terdapat di lokasi penelitian. Penelitian ini menggunakan studi kasus tunggal (Single Case Study) karena menggunakan satu isu atau kasus yang muncul dalam satu penelitian atau dalam satu lokasi.

Penelitian ini membahas tentang gambaran peluang usaha yang diperoleh para pemilik usaha di sekitar kampus sebagai dampak dari berdirinya Universitas Buana Perjuangan Karawang sejak tahun 2014, bagaimana pemahaman para pemilik usaha tersebut terhadap keberadaan UBP Karawang, dan harapan para mereka terhadap UBP Karawang. Kasus ini merupakan kasus tunggal karena menyangkut hanya satu kasus yaitu gambaran tentang peluang usaha para pemilik usaha di sekitar kampus UBP Karawang.

Penelitian dilaksanakan di lokasi sekitar kampus UBP Karawang (radius 500 m), Desa Puseurjaya dan Sirnabaya dan Sirnabaya Kecamatan Telukjambe Timur Karawang. Sedangkan waktu penelitian mulai bulan Januari sampai dengan Agustus 2017.

Tahapan penelitian kualitatif yang dilakukan adalah tahapan persiapan yaitu penyusunan proposal penelitian, menyusun dan mengembangkan instrumen 
(pedoman wawancara dan check list), uji coba instrument, pengumpulan data, pengolahan, analisis data dan pengambilan kesimpulan penelitian.

Teknik penentuan responden menggunakan Purposive Sampling. Responden terdiri dari para pemilik usaha (usahawan) di sekitar kampus UBP Karawang, tokoh masyarakat, serta unsur pimpinan UBP Karawang. Jenis usaha yang dipilih adalah usaha yang banyak melayani mahasiswa yaitu warung makan untuk mewakili usaha produksi, tempat kos untuk mewakili usaha jasa, serta jasa photocopy dan alat tulis kantor untuk mewakili usaha jasa yang dipadukan dengan penjualan produk. Tokoh masyarakat yang dipilih adalah Ketua RT dengan pertimbangan bahwa ketua RT mengetahui segala permasalahan yang ada di masyarakat. Pimpinan yang dipilih adalah Ketua Lembaga Penelitian dan Pengabdian kepada Masyarakat UBP Karawang, dengan pertimbangan lembaga tersebut memiliki kegiatan pengabdian kepada masyarakat yang salah satunya bertema "Pengabdian kepada Masyarakat Lingkar Kampus”.

Data primer merupakan data yang dikumpulkan oleh peneliti berdasarkan jawaban-jawaban yang diberikan responden pada saat wawancara mendalam serta hasil observasi yang dilakukan peneliti selama penelitian berlangsung.

Data sekunder bersumber dari Kantor Desa mengenai data kependudukan Desa Puseurjaya dan Desa Sirnabaya.

Teknik pengumpulan data untuk mendapatkan data primer melalui observasi denggan menggunakan check list, serta wawancara mendalam (in-depth interview) dengan menggunakan pedoman wawancara. Pedoman wawancara berupa daftar pertanyaan yang telah disusun oleh peneliti yang tidak bersifat kaku (dapat dikembangkan lebih lanjut sesuai dengan situasi dan informasi yang diperoleh saat wawancara). Selama wawancara, jawaban-jawaban responden direkam dengan menggunakan recorder.

Teknik pengumpulan data lainnya yaitu melalui dokumen-dokumen di kantor desa berupa data kependudukan meliputi jumlah dan status pekerjaan penduduk Desa Puseurjaya dan Desa Sirnabaya. 
Instrumen yang digunakan adalah pedoman wawancara dan check list mengenai persepsi masyarakat terhadap keberadaan UBP Karawang meliputi dampak positif dan negatif yang ditimbulkan oleh keberadaan UBP Karawang, harapan masyarakat terhadap keberadaan UBP Karawang, peluang usaha meliputi peluang dalam memperoleh konsumen, pekerja, bahan baku dan modal, orang-orang yang terlibat dalam usaha, kendala yang dihadapi dalam memperoleh peluang, serta keberhasilan usaha yang diraih oleh para usahawan.

Validasi data dalam penelitian kualitatif ini dilakukan dengan triangulasi sumber, triangulasi metode dan triangulasi data. Triangulasi sumber yaitu dengan menggunakan responden yang berbeda untuk melakukan cross-check serta data dengan telaah dokumen (data sekunder). Sedangkan triangulasi metode dilakukan dengan menggunakan beberapa metode dalam pengumpulan data yaitu dengan menggunakan metode wawancara mendalam dan metode observasi. Triangulasi data dilakukan dengan meminta umpan balik dari responden berupa saran dan informasi tambahan untuk memperbaiki kualitas kesimpulan dari data yang telah dikumpulkan.

Data yang terkumpul dari formulir check list dan data sekunder akan diolah dan disajikan dalam bentuk tabel dan narasi. Data yang diolah hanya data yang berhubungan dengan tujuan penelitian dan data yang mendukung pembahasan penelitian. Data hasil wawancara mendalam diolah secara manual. Analisis data dilakukan secara manual dengan menggunakan analisis isi (content analysis). Teknik menginterpretasikan hasil analisis dengan dua cara yaitu (a) memperluas analisis dengan mengajukan pertanyaan. Hasil analisis mungkin masih miskin dengan makna, dengan pengajuan beberapa pertanyaan hasil tersebut bisa dilihat maknanya, (b) menghubungkan hasil-hasil analisis dengan literatur.

Penarikan kesimpulan atau verifikasi merupakan kegiatan di akhir penelitian kualitatif. Kesimpulan yang ditarik segera diverifikasi dengan cara melihat dan mempertanyakan kembali sambil melihat catatan lapangan agar memperoleh pemahaman yang lebih tepat.

\section{HASIL DAN PEMBAHASAN PENELITIAN}

148. 


\section{Aspek Sosial Ekonomi Daerah Penelitian}

Kecamatan Telukjambe Timur merupakan salah satu dari 30 kecamatan di Kabupaten Karawang. Kecamatan ini berada pada wilayah dengan batas-batas sebagai berikut: di sebelah Utara berbatasan dengan Kecamatan Karawang Timur, di sebelah Selatan berbatasan dengan Kabupaten Bekasi dan Kecamatan Pangkalan, di sebelah Barat berbatasan dengan Kecamatan Teluk Jambe Barat dan di sebelah Timur berbatasan dengan Kecamatan Ciampel. Kecamatan Telukjambe Timur merupakan daerah kawasan industri dan pertanian, mencakup 9 (sembilan) Desa yang meliputi 41 Dusun, 82 RW dan 370 RT. Sembilan desa yang terdapat di Kecamatan Telukjambe Timur terdiri dari: Desa Teluk Jambe, Desa Pinayungan, Desa Sirnabaya, Desa Puseur Jaya, Desa Sukaluyu, Desa Wadas, Desa Sukaharja, Desa Sukamakmur dan Desa Purwadana. Pada tahun 2016, luas wilayah Kecamatan Teluk Jambe Timur adalah $40 \mathrm{~km}^{2}$ berjumlah penduduk 112.023 orang yang terdiri dari $35.600 \mathrm{KK}$ dengan tingkat kepadatan 2.792 orang per $\mathrm{km}^{2}$ (Telukjambe Timur dalam Angka, 2017). Adapun jarak Kecamatan Teluk Jambe Timur ke Ibu Kota Kabupaten Karawang adalah $6 \mathrm{~km}$ dengan waktu tempuh sekitar 15 menit. Kecamatan ini dilintasi jalan tol Jakarta-Cikampek, dan wilayah yang berada di sebelah selatan jalan tol Jakarta-Cikampek. Kecamatan ini termasuk dalam kecamatan dengan jumlah penduduk terbanyak dan terpadat di Kabupaten Karawang http://www.karawangkab.go.id/sites/default/files/pdf/Telukjambe\%20Timur.pdf. Di kecamatan ini terletak dua perguruan tinggi yaitu Universitas Singaperbangsa Karawang (Unsika) yang sudah dinegerikan dan Universitas Buana Perjuangan Karawang (UBP Karawang), suatu perguruan tinggi swasta yang didirikan oleh Yayasan sebagai pengganti Unsika.

Salah satu desa di Kecamatan Telukjambe Timur adalah Desa Puseurjaya. Desa ini merupakan kawasan pengembangan perumahan di Kota Karawang karena lokasinya yang strategis. Di desa ini terletak kampus utama Universitas Singaperbangsa Karawang dan Universitas Buana Perjuangan Karawang tepatnya di Dusun Kaum Jaya. Selain di Dusun Kaum Jaya, UBP Karawang juga memiliki laboratorium di Desa Sirnabaya tepatnya Dusun Kaum Raya. Mayoritas penduduk di 
desa ini bekerja sebagai buruh, PNS, dan karyawan swasta dikarenakan dekat dengan Kawasan industri dan pusat pemerintahan Kota Karawang. Desa seluas 3,09 km² ini memiliki penduduk 8.680 jiwa terdiri dari 2.659 KK dengan kepadatan 2.809 orang per $\mathrm{km}^{2}$. Batas Desa Puseurjaya, sebelah Utara Sungai Citarum dan kecamatan Karawang Barat, sebelah Barat Desa Sukaharaja dan Desa Sukaluyu, sebelah Timur dan Selatan Desa Sirnabaya. Desa Sirnabaya adalah salah satu desa di Kecamatan Teluk Jambe Timur yang mempunyai luas wilayah $11,51 \mathrm{~km}^{2}$. Jumlah penduduk Desa Sirnabaya sebanyak 9.370 jiwa yang terdiri dari 3.201 orang laki-laki dan 6.169 orang perempuan dengan jumlah kepala keluarga sebanyak $2.814 \mathrm{KK}$, dengan kepadatan penduduk 814 orang per $\mathrm{km}^{2}$ (Telukjambe Timur dalam Angka, 2017).

Batas-batas administratif Pemerintahan Desa Sirnabaya Kecamatan Teluk Jambe Timur sebagai berikut sebelah Utara berbatasan dengan Desa Puseurjaya Kecamatan Telukjambe Timur, sebelah Timur berbatasan dengan Desa Telukjambe dan Pinayungan Kecamatan Telukjambe Timur, sebelah Selatan berbatasan dengan tanah kehutanan, dan sebelah Barat berbatasan dengan Desa Puseurjaya Kecamatan Telukjambe Timur.

Berdasarkan status pekerjaan, persentase angkatan kerja yang menganggur di Desa Sirnabaya masih cukup tinggi yaitu 170 orang dari 461 orang angkatan kerja atau 36,87 \% bahkan di Desa Puseurjaya mencapai 73,12\% yaitu 370 orang dari 506 orang angkatan kerja.

Keadaan Penduduk Desa Sirnabaya dan Puseurjaya Kecamatan Telukjambe Timur Kabupaten Karawang

\begin{tabular}{|c|c|c|c|c|c|c|c|}
\hline $\begin{array}{c}\text { Nama } \\
\text { Desa }\end{array}$ & Bekerja & Pengangguran & $\begin{array}{c}\text { Jumlah } \\
\text { Angkatan } \\
\text { Kerja }\end{array}$ & Bersekolah & $\begin{array}{c}\text { Mengurus } \\
\text { Rumah } \\
\text { Tangga }\end{array}$ & $\begin{array}{c}\text { Bukan } \\
\text { Angkatan } \\
\text { Kerja }\end{array}$ & $\begin{array}{c}\text { Total } \\
\text { Penduduk }\end{array}$ \\
\hline Sirnabaya & 291 & 170 & 461 & 241 & 421 & 662 & 1.123 \\
\hline Puseurjaya & 136 & 370 & 506 & 255 & 999 & 1.254 & 1.760 \\
\hline
\end{tabular}

Sumber: Telukjambe Timur dalam Angka, 2017

150. 


\section{Dampak Keberadaan UBP}

Dampak dapat berupa dampak positif dan dampak negatif. Pengertian dampak positif adalah pengaruh yang menimbulkan kebaikan kepada orang lain. Sedangkan dampak negatif adalah pengaruh yang menimbulkan keburukan kepada orang lain atau masyarakat.

Keberadaan perguruan tinggi di Puseurjaya dan Sirnabaya mendapat tanggapan dari responden baik tanggapan yang bersifat positif maupun tanggapan negatif. Tanggapan yang bersifat positif diberikan oleh responden yaitu dengan adanya perguruan tinggi di Puseurjaya dan Sirnabaya ada dua hal positif yang dirasakan. Pertama, membuka peluang usaha sehingga banyak tenaga kerja setempat yang terserap baik itu membuka usaha sendiri maupun bekerja pada pengusaha lain. Kedua memunculkan motivasi bagi anak-anak responden untuk melanjutkan pendidikan pada jenjang tertinggi, sehingga pada akhirnya nanti dapat membangun daerahnya.

Tanggapan negatif diberikan oleh responden menyangkut pertama semakin banyaknya lahan yang beralih fungsi sehingga banyak anggota masyarakat yang berganti pekerjaan. Pekerjaan yang sekarang dijalani lebih banyak pekerjaan kasar yang tidak memerlukan keterampilan sehingga penghasilan yang didapat pun tidak banyak. Akibatnya penghidupan masyarakat setempat tetap saja tidak ada perubahan bahkan dirasakan semakin menurun karena mereka sekarang tidak mempunyai lahan pertanian lagi. Walaupun sebenarnya hal ini sudah terjadi sejak lama saat UBP Karawang belum berdiri. Tanggapan negatif lainnya adalah dampak dari perilaku buruk mahasiswa. Mahasiswa sebagai panutan bagi anak-anak setempat jika berperilaku buruk akan dijadikan bahan untuk ditiru. Dengan demikian banyak anak muda setempat yang berperilaku buruk seperti pergaulan yang lebih bebas dibandingkan saat Desa Puseurjaya dan Sirnabaya masih sepi.

Undang-undang Nomor 12 tahun 2012 tentang Pendidikan Tinggi

menyatakan bahwa Perguruan tinggi adalah satuan pendidikan yang menyelenggarakan pendidikan tinggi. Perguruan tinggi terdiri dari Perguruan Tinggi 
Negeri (PTN) dan Perguruan Tinggi Swasta (PTS). PTN diselenggarakan oleh pemerintah, sedangkan PTS didirikan dan diselenggarakan oleh masyarakat. Dalam undang-undang tersebut juga dijelaskan bahwa Pendidikan adalah usaha sadar dan terencana untuk mewujudkan suasana belajar dan proses pembelajaran agar peserta didik secara aktif mengembangkan potensi dirinya untuk memiliki kekuatan spiritual keagamaan, pengendalian diri, kepribadian, kecerdasan, akhlak mulia, serta keterampilan yang diperlukan dirinya, masyarakat, bangsa, dan negara. Suatu perguruan tinggi baik negeri maupun swasta berkewajiban untuk melaksanakan Tridharma Perguruan Tinggi yaitu kewajiban perguruan tinggi untuk menyelenggarakan pendidikan, penelitian, dan pengabdian kepada masyarakat.

Dari uraian di atas maka seharusnya suatu perguruan tinggi lebih banyak memberikan damnpak positif terhadap lingkungannya dibandingkan dengan dampak negatif.

Desa Puseurjaya dan Sirnabaya yang merupakan desa yang tergolong cukup maju tidak banyak memiliki masalah dengan sarana dan sumberdaya manusia yang berpendidikan. Hal ini disebabkan di Desa Puseurjaya dan Sirnabaya sudah tersedia pada semua jenjang pendidikan baik sekolah dasar, menengah bahkan perguruan tinggi. Kebutuhan dan masalah yang dihadapi oleh responden dari Desa Puseurjaya dan Sirnabaya adalah masih sulitnya masyarakat setempat untuk melanjutkan pendidikan tinggi, terutama Perguruan Tinggi Negeri. Kesulitannya adalah ketiadaan biaya karena biaya untuk melanjutkan pendidikan ke perguruan tinggi dirasakan mahal. Selain itu juga karena kemampuan secara intelektual anggota masyarakat setempat dirasakan masih ada di bawah para pendatang. Dengan adanya perguruan tinggi swasta seperti UBP Karawang di desa tersebut diharapkan anak-anaknya dapat melanjutkan di perguruan tinggi tersebut. Hal ini mengingat biaya untuk melanjutkan studi di UBP Karawang cukup terjangkau karena dicicil serta tidak memerlukan biaya transpor dan tempat tinggal.

Sedangkan kebutuhan dari aspek ekonomi lebih banyak berhubungan dengan pekerjaan yang dilakukan. Kurangnya modal dan keterampilan menjadi permasalahan yang paling banyak dihadapi oleh responden disamping pengangguran yang merata 
dirasakan oleh semua responden. Untuk peluang usaha, sebagian besar usaha yang ada di sekitar kampus dimiliki oleh orang-orang yang memiliki modal dari luar Karawang.

Potensi yang dimiliki oleh desa yang menjadi lokasi penelitan adalah letak geografis yang dekat dengan industri, kampus serta terletak di kecamatan Telukjambe Timur yang notabene dekat dengan pusat kota Karawang. Hal ini menjadi potensi yang menyebabkan akses masyarakat dari desa tersebut mudah. Masyarakat jika akan memasarkan ataupun membuka usaha lain sangat mudah dengan akses seperti ini karena selain mudah transportasi juga banyaknya orang luar yang datang khususnya keluarga mahasiswa.

\section{Peluang Usaha}

\section{Konsumen}

Berdasarkan observasi peluang usaha di Desa Puseurjaya dan Desa Sirnabaya sangat besar, mengingat perkembangan kedua desa ini sangat pesat. Perkembangan ini disebabkan oleh beberapa hal antara lain:

a. Kedua desa ini relatif berjarak dekat dengan kawasan industri Karawang International Industrial City (KIIC).

b. Terdapat dua perguruan tinggi yang berbentuk universitas yang terletak di kedua desa ini.

c. Semakin bertambah banyaknya perumahan di desa ini.

d. Kedua desa ini berdekatan dengan perumahan elit Galuh Mas, lengkap dengan mall, rumah makan, arena hiburan dan lain-lain.

e. Perkembangan daerah berkorelasi positif dengan bertambahnya jumlah penduduk, karena semakin banyak pendatang lengkap dengan anggota keluarganya.

Dari identifikasi kondisi di atas dapatlah dipahami mengapa di kedua desa ini semakin menjamur berberbagai jenis usaha antara lain kuliner (rumah atau warung makan), kamar kos, cucian (laundry), bahan bangunan dan lain-lain. Hal ini disebabkan semakin bertambahnya jumlah penduduk di wilayah tersebut. Dengan semakin bertambahnya jumlah penduduk berarti semakin bertambah banyaknya 
kosumen potensial untuk setiap bisnis yang berkembang di wilayah tersebut. Hal ini sejalan dengan pendapat Hendro (2011) yang menyatakan bahwa salah satu sumber peluang atau kesempatan usaha adalah adanya perubahan yang terjadi pada lingkungan. Peluang besar yang sering muncul menjadi sebuah bisnis adalah perubahan yang terjadi di lingkungan antara lain perubahan global, perubahan lingkungan, perubahan peraturan, perubahan musim, perubahan gaya hidup, perubahan tingkat kebutuhan tentang, pola hidup yang lebih sehat, perubahan tingkat tekanan pekerjaan yang semakin tinggi (berat), hal ini dapat membuka peluang untuk memberikan sebuah layanan hiburan bagi pekerja tersebut, perubahan teknologi informasi dan komunikasi seperti kemajuan teknologi hand phone dan internet, serta perubahan tingkat pertumbuhan pemilik kendaraan.

\section{Orang yang terlibat dalam usaha serta Kualitas dan Kuantitas Sumber daya} Manusia

Dari hasil observasi peneliti diperoleh informasi bahwa pemilik usaha di sekitar kampus UBP Karawang umumnya pendatang, bukan penduduk desa Puseurjaya ataupun Sirnabaya; baik pada usaha kuliner atau warung makan, jasa photocopy, ataupun kamar kos. Sebagian besar mereka adalah pengusaha dari luar desa yang mengembangkan usahanya di kedua desa tersebut.

Dilihat dari jumlah sumberdaya usaha yang terdapat di sekitar Kampus UBP Karawang nampaknya tidak memerlukan jumlah karyawan yang banyak, dengan keterampilan yang sudah mereka miliki serta umumnya mereka membawa karyawan dari tempat asal. Kalau mereka memerlukan karyawan untuk pekerjaan kasar misalnya mencuci piring, karyawan untuk 'beres-beres' di tempat kos barulah mereka menerima lowongan pekerjaan untuk penduduk setempat. Bagi orang yang memulai usaha dapat dengan mudah mendapatkan tenaga kerja di kedua desa ini, tetapi sering orang yang ingin bekerja tersebut tidak memiliki keterampilan yang diperlukan tetapi ingin memperoleh gaji atau upah yang besar. Dengan demikian dapat disimpulkan bahwa dilihat dari kuantitas sumberdaya manusia tidak ada masalah di kedua desa ini, tapi dengan kualitas yang terbatas.

\section{Bahan Baku}

154.

Jurnal Manajemen \& Bisnis Kreatif 
Bahan baku yang diperlukan untuk usaha yang mereka jalankan tidak sulit ditemukan, mengingat lokasi kedua desa sangat strategis. Bahan baku untuk warung makan mereka dapat dengan mudah mendapatkannya di pasar Karawang ataupun pasar Johar. Bahan baku kayu untuk pembangunan kamar kos dapat dengan mudah diperoleh dari toko bangunan yang sudah tersedia di desa yang sama. Demikian juga kertas photocopy dapat diperoleh di mal yang berlokasi di lokasi Galuh Mas ataupun di toko-toko besar yang berlokasi di Jalan Tuparev. Dengan demikian dapat disimpulkan bahwa bahan baku untuk usaha sangat mudah diperoleh di kedua desa ini.

\section{Modal}

Modal merupakan hal yang hampir selalu ditemukan menjadi kendala untuk memulai suatu usaha. Modal yang digunakan oleh para usahawan tersebut merupakan modal pengembangan usaha, karena mereka adalah orang-orang yang sudah lama bergelut dalam bidang yang sama di tempat lain. Bagi orang baru yang akan memulai usaha hal ini menjadi kendala karena usaha-usaha tersebut di atas memerlukan modal yang tidak sedikit.

\section{Kendala dalam Menangkap Peluang Usaha}

Dari hasil wawancara diperoleh informasi bahwa sumberdaya manusia serta modal menjadi kendala bagi penduduk Desa Puseurjaya dan Sirnabaya untuk bersaing dalam menangkap peluang usaha.

\section{Sumberdaya manusia.}

Dari observasi dan hasil wawancara diperoleh informasi bahwa umumnya penduduk setempat kurang memiliki keterampilan dalam usaha serta memiliki motivasi yang rendah dan kurang mampu dalam menghadapi resiko dalam memulai usaha. Hal ini dapat dilihat dari kasus tukang comro dan misro (sejenis makanan yang dibuat dari singkong). Dia sudah memiliki pelanggan yang banyak tetapi kadangkala tidak berjualan karena banyaknya gangguan misalnya saudara punya hajat, keluarga sakit dan lain sebagainya, sehingga lokasi yang digunakan untuk berjualan digunakan secara menetrap oleh penjual lain saat dia tidak berjualan. Hal 
ini menyebabkan dia kehilangan kesempatan dalam menangkap peluang dan tempat yang strategis.

\section{Modal.}

Modal merupakan kendala lainnya. Orang-orang yang menjalankan usaha di sekitar kampus UBP Karawang adalah pendatang yang memiliki modal, pengalaman serta usahanya sudah 'berjalan' di tempat lain, sehingga bagi mereka modal tidak jadi kendala. Tetapi bagi penduduk setempat yang baru, memulai usaha hal ini sudah tentu menjadi kendala, karena mereka umumnya tidak memiliki modal. Dari beberapa tempat kos terdapat pemiliknya penduduk setempat yang menyewakan kamar-kamarnya yang kosong kepada mahasiswa, bukan membangun kamar baru. Demikian juga pemilik usaha photocopy dan warung makan. Mereka umumnya bukan penduduk setempat tetapi dari daerah lain yaitu dari Kecamatan Rengasdengklok, Tegal bahkan Sumatra.

\section{Keberhasilan Usaha}

Suatu usaha dikatakan berhasil di dalam usahanya apabila setelah jangka waktu tertentu usaha tersebut mengalami peningkatan baik dalam permodalan, skala usaha, hasil atau laba, jenis usaha atau pengelolaan (Erliah, 2007). Sedangkan Priyanto (2009) mengatakan bahwa seseorang yang memiliki motivasi kewirausahaan tinggi dan digabung dengan kemampuan manajerial yang memadai akan menyebabkan dia sukses dalam usahanya.

Dari hasil wawancara dengan pemilik usaha kamar kos asal Rawamerta, dengan penyewa kios photocopy maupun penyewa kantin di belakang UBP Karawang serta pemilik usaha warung makan Padang di depan kampus UBP Karawang ada perbedaan dalam perkembangan usaha.

Bagi pemilik usaha kamar kos dan kayu bahan bangunan, adanya Unsika dan UBP Karawang dapat meningkatkan omzetnya. Dia sudah mencoba usaha sejak tahun 2000 mulai dari kantin di pabrik, warnet dan kayu semuanya menurun karena banyak saingan. Yang menguntungkan bagi dia adalah usaha menyewakan kamar kos kepada mahasiswa. Pada tahun 2008 memulai dengan menyewakan 5 (lima) kamar sekarang sudah berkembang menjadi 22 (dua puluh dua) kamar. Awal tahun

156.

Jurnal Manajemen \& Bisnis Kreatif 
2008 omzetnya Rp. 1.500.000,00 per bulan, sekarang menjadi usaha utama untuk memenuhi kebutuhan sehari-hari, dengan omzet Rp. 14.000.000,00 per bulan dari 34 orang mahasiswa Unsika. Sekarang usaha dikembangkan ke arah kontrakan toko ada 5 (lima) unit toko dengan omzet Rp. 120.000.000,00 per tahun. Tahun 2016 dia membuka toko kelontong dan makanan ringan di dekat Laboratorium UBP Karawang. Toko ini pelanggannya 80\% mahasiswa UBP Karawang. Dia menjalankan usaha sendiri bersama suami dan seorang anaknya yang sudah sarjana. Dia juga empat orang pekerja dari luar Karawang. Dia hanya mempekerjakan satu orang dari desa ini karena pekerjaannya tidak rapi, sering bolos, dan tidak jujur. Tahun 2017 dia mengusahakan makanan cilor (sejenis makanan 'camilan' yang terbuat dari kanji (aci) dan telur) dengan pendapatan bersih Rp, 750.000,00 per hari. Dia tidak memiliki niat untuk memperluas usaha.

Pemilik usaha jasa photocopy yang sekaligus menjual alat tulis kantor menuturkan bahwa usaha tersebut merupakan pengembangan dari usaha sejenis yang berlokasi di Unsika. Pada awal UBP Karawang didirikan, dia menyewa kios non permanen di halaman kampus UBP Karawang. Saat itu pelanggannya mahasiswa Unsika yang tempat kuliahnya di kampus UBP Karawang (saat itu masih Kampus 2 Unsika). Karena tidak ada saingan, usahanya berkembang pesat. Sekarang dia menyewa kios dari Koperasi UBP Karawang seharga Rp. 25.000.000,00 per tahun. Omzet per hari dapat mencapai Rp. 600.000,00 sampai Rp. 800.000,00 per hari. Pelanggannya terdiri dari mahasiswa dan dosen Unsika dan UBP Karawang.

Hasil wawancara dengan pemilik usaha warung makan di kantin belakang UBP Karawang agak berbeda dengan pemilik usaha yang terdahulu. Pemilik usaha warung makan ini mengatakan baru pertama kali berjualan. Saat ini karena sedang libur omzetnya mencapai Rp. 800.000,00 sampai 1.000.000,00 per hari. Dia berjualan hanya lima hari dalam seminggu yaitu hari Senin sampai dengan Jum'at. Modal awal Rp. 1.000.000,00. Jenis makanan hanya ada pepes dan nasi. Terus berkembang menjadi usaha makan, minuman, cilor dan lain-lain. Saat libur keuntungan kotor Rp. 300.000,00 per hari. Keuntungan bersih setelah dipotong sewa kantin, makan dan upah tenaga kerja adalah Rp. 1.000.000,00 sampai dengan Rp, 
1.500.000,00 seminggu. Saat perkuliahan berjalan keuntungan bersih Rp. 3.000.000,00 per minggu. Keuntungan terbesar dari makanan camilan cilor. Saat ada perkuliahan penjualan cilor mencapai 2.500 tusuk per hari, saat libur antara 700 sampai dengan 1.500 tusuk dengan harga Rp. 2.000,00 per tiga tusuk. Usaha ini melibatkan seorang ibu, dua orang anak dan seorang menantu. Masing-masing mendapatkan upah/gaji bersih Rp. 800.000,00 per minggu jika saat perkuliahan, sedangkan saat liburan masing-masing hanya memperoleh upah Rp. 400.000 per minggu.

Pemilik usaha warung makan Padang yang berlokasi di depan gerbang UBP Karawang mengatakan bahwa dia sekeluarga sudah setahun lebih berjualan di situ. Sebelumnya dia menjalankan usaha warung makan di Sumatra. Dia mengatakan bahwa usaha warung makan di Telukjambe ini merupakan pengembangan dari usaha di Sumatra. Sekarang usaha warung makan di Sumatra dikelola oleh kakaknya, sedangkan dia fokus mengelola usaha warung makan di tempat ini. Sekarang warung makan ini menjual nasi Padang 'paket hemat' yang disukai oleh mahasiswa karena murah meriah. Dalam sehari warung nasi Padang ini dapat 'menghabiskan' sekitar $15 \mathrm{~kg}$ beras. Sebagai perkiraan jika per $\mathrm{kg}$ beras menjadi 8 porsi 'paket hemat' berarti dalam satu hari terjual 120 porsi. Apabila dikalikan dengan harga paket hemat yaitu Rp. 10.000,00 per porsi, maka dalam sehari dia sudah mengantongi Rp. 1.200.000,00.

\section{Kendala serta Harapan Usaha}

Kendala. Kendala pada berbagai jenis usaha itu berbeda. Pemilik usaha tempat kos mengutarakan bahwa menyewakan kamar kos dan toko merupakan usaha teraman dibandingkan usaha lainnya. Walaupun kendalanya banyak anak kos yang bayar telat dan kurang sopan serta etikanya rendah. Sedangkan pemilik usaha warung makan di belakang kampus UBP Karawang memiliki kaitan yang lebih erat dengan kegiatan kampus, dia menyatakan bahwa kendalanya adalah banyaknya waktu libur sehingga mengurangi omzet. Kendala lainnya adalah kantin tersebut bukan milik UBP Karawang sehingga di samping bayar sewa yang mahal juga dia khawatir kalau waktunya tiba kantin itu akan dibongkar. Kekhawatiran dibongkarnya kios juga

158.

Jurnal Manajemen \& Bisnis Kreatif 
diutarakan pula oleh pemilik usaha jasa photocopy. Sedangkan pemiliki usaha warung makan Padang tidak terlalu memperlihatkan kekhawatiran walaupun kampus libur tetap masih ada pembeli karena lokasi warung makan tersebut di pinggir jalan besar di luar kampus. Hanya saja omzet menurun jika mahasiswa libur kuliah.

\section{Harapan.}

Selain kendala, harapan para usahawan tersebut berbeda juga, akan tetapi memiliki kaitan dengan UBP Karawang. Pemilik tempat kos yang juga pemilik warung di dekat laboratorium UBP Karawang menyatakan bahwa dia merasa kurang puas dengan keadaan saat ini karena banyak mahasiswa yang nitip motor tanpa bayar sewa padahal tanggung jawabnya besar. Kekhawatiran sering timbul karena sering mahasiswa kehilangan motor. Dia berharap di laboratorium sebaiknya ada tempat parkir, karena banyak mahasiswa yang kehilangan motor. Sedangkan pemilik usaha warung makan berharap agar UBP Karawang memiliki kantin sehingga jika bangunan kantin yang sekarang ditempati itu dibongkar, maka para pemilik usaha makanan dan minuman yang ada di kantin tersebut dapat melanjutkan usahanya. Harapan tidak dibongkarnya bangunan di belakang kampus juga diutarakan oleh pemilik jasa photocopy. Sedangkan pemilik usaha warung nasi Padang berharap mahasiswa UBP Karawang semakin banyak sehingga warung makannya semakin laku.

\section{Program Pengabdian kepada Masyarakat UBP Karawang.}

Dari hasil wawancara dengan Ketua Lembaga Penelitian dan Pengabdian kepada Masyarakat (LPPM) UBP Karawang diperoleh informasi bahwa untuk menghindari terbentuknya budaya kampus sebagai 'menara gading' di tengah-tengah masyarakat, maka terdapat beberapa program yang ada kaitannya dengan pembinaan masyarakat sekitar kampus. Program tersebut ada yang sudah dilaksanakan yaitu bakti sosial kepada masyarakat sekitar kampus. Kegiatan yang dilaksanakan pada bulan Mei tahun 2017 ini merupakan bentuk kepedulian dari kerjasama antara UBP Karawang dengan Universiti Teknologi MARA (UiTM) Malaysia yang melibatkan

pimpinan, dosen dan mahasiswa dari kedua perguruan tinggi tersebut. Kegiatan yang berupa pemberian santuan kepada orang tua, anak yatim dan dhuafa ini selain 
bertujuan untuk mempererat hubungan antara kedua perguruan tinggi tersebut, juga untuk menanamkan sikap peduli sivitas akademika kedua perguruan tinggi terhadap masyarakat.

Program lainnya yang belum dilaksanakan adalah pengabdian kepada masyarakat lingkar kampus dan Kuliah Kerja Nyata $(\mathrm{KKN})$. Program pengabdian kepada masyarakat lingkar kampus direcanakan akan diikuti oleh dosen dari setiap program studi di lingkungan UBP Karawang. Sedangkan KKN akan mulai diselenggarakan pada semester genap tahun 2017/2018 di empat kecamatan yaitu Kecamatan Telukjambe Timur, Kecamatan Telukjambe Barat, Kecamatan Pangkalan dan Kecamatan Ciampel.

\section{KESIMPULAN DAN SARAN}

\section{$\underline{\text { Kesimpulan }}$}

Dari penelitian ini dapat disimpulkan bahwa:

1. Peluang untuk usaha di sekitar kampus UBP Karawang sangat besar, tetapi belum dimanfaatkan oleh penduduk sekitar kampus.

2. Kendala yang dihadapi berupa rendahnya motivasi, kurangnya keberanian menanggung resiko, rendahnya keterampilan, kurangnya pengalaman dalam bekerja dan menjalankan usaha serta kurangnya permodalan yang menyebabkan saat ini masyarakat setempat tidak dapat bersaing dengan para usahawan pendatang yang sudah berpengalaman.

\subsection{Saran}

1. Adanya pemberian motivasi, keterampilan dan pembinaan usaha kepada masyarakat sekitar kampus sehingga mereka dapat bersaing dengan para pendatang.

2. Adanya pembinaan moral dan etika kepada mahasiswa UBP Karawang khususnya agar tidak memberikan dampak negatif kepada masyarakat sekitar kampus terutama kepada kaum muda. 
3. Adanya pembinaan keluarga dari dosen yang sesuai bidangnya khususnya terhadap anak-anak muda di sekitar kampus sehingga mereka tidak terjerumus ke dalam pergaulan bebas.

\section{DAFTAR PUSTAKA}

Coulter, M.A. 2003. Entrepreneurship in Action, $2^{\text {nd }}$ Edition. Missouri State University.

Djamaludin, A 2009. "Social Environment and Business." General Business Environment: Syllabus and Material. MM UGM. Yogyakarta.

Hendro. 2011. Kewirausahaan. Erlangga, Jakarta

KBBI Online. 2015. http://kbbi.web.id/dampak. Diunduh 1 Desember 2016.

Kuratko, D. F. Kuratko. 2004. Entrepreneurship Education in the $21^{\text {st }}$ Century: From Legitimazion to Leadership. A Coleman Foundation White Paper. USASBE National Conference.

Noor, H., F. 2007. Ekonomi manajerial. Jakarta: PT Raja Grafindo Persada

Priyanto, S., H. 2009. Mengembangkan Pendidikan Kewirausahaan di Masyarakat. Andragogia- Jurnal PNFI, 1(1), pp. 57-82.

Stoner, James A.F. (2006). Management.Englewood Cliffs, N.J. : Prentice Hall, Inc.

Riyanti, B.P,D. (2003). Kewirausahaan Dari Sudut Pandang. Psikologi Kepribadian. Jakarta : Grasindo.

Suryana. 2011, Kewirausahaan, Jakarta: Salemba Empat.

Tulus Tambunan. 2002. Perdagangan Internasional dan Neraca Pembayaran: Teori dan Temuan Empiris. Jakarta: LP3ES

Undang-undang No. 12 tahun 2012 tentang Pendidikan Tinggi.

Website Resmi Kabupaten Karawang. Sejarah Karawang. http://karawangkab.go.id/index.php?option=com_content\&task=view\&id=12 \&Itemid=94. Diunduh tanggal 9 Oktober 2017 